\title{
FORESTRY IN POST-WAR REHABILITATION ${ }^{1}$
}

$\mathrm{R}$

EHABILITATION, in the sense in which it will be used in this report, means the putting back into peace time life, not pre-war conditions, the men and women of the armed forces, from the munition plants and those who have been employed in temporary government work. This must also include young men reaching employable age. The problem of dealing with men who have taken the places of those who have been in war services and who will want their jobs back must also be settled.

It is very easy to point out what might be done. The real problem is to work out concrete and workable plans. Any suggestions we have to make to the proper authorities must be worked out in considerable detail. We do do not want to repeat the mistakes of the last war-one of which was the placing of men on farms regardless of their aptitude or fitness for such work.

The most important thing is to place men in congenial jobs in which they can take an interest. Otherwise they will not succeed.

It will be absolutely necessary to find out what the men and women with whom we shall have to deal are fitted for before trying to place them. If they are not skilled enough to fill useful positions we must give them the right kind of training. After the excitement of war it is hard for men to settle down and the discipline and routine of military life do not tend to make men self reliant or to foster initiative. We must do everything we can to make the transition to peace time conditions as easy as possible. This is very important as men who have been flying won't want to work on farms or in routine office jobs nor will men of education and above average I.Q.'s want to take manual jobs in which they would probably be failures.

The best procedure to follow is that which was used in inducting men into the armed forces,-physical and psychological examinations and intelligence and aptitude tests.

Men who have been housed, clothed, fed and entertained by the government for considerable periods of time will very naturally feel that they should have positions in which they will be able to earn the means to live in comparable fashion.

Many of the kinds of work which will be mentioned will require the housing and feeding of men and their transportation to and from work. All of this can best be taken care of by the army which has the necessary experience and will have all the necessary equipment. In many cases training and internment camps would be all ready to use. Returning offcers could step right into such jobs. There should be no military drill. The Army should have nothing to say about either the kind of work or its management. The men should be turned over to foresters in the morning and should be under their orders and supervision until returned to camp. My colleague on this committee is not in agreement with me on this method but it has been so successful in the management of the Civilian Conservation Corps in the United

1. Report of the standing committee presented by the Chairman, Mr. Ellwood Wileon, at the Thirty-fifth Annual Moeting, Canadian Society of Forest Engineers. 
States that it would be folly not to profit by their experience. Foresters are competent to do the whole thing but they have not had the experience of the army men nor have they the equipment. It would never do to have the appalling conditions of the labour camps at Kingston and Petawawa repeated.

It may be possible to find employment for some men on farms and this can best be accomplished through local boards.

The various government forest services could absorb a few men and should, like Quebec, train others for positions.

What has forestry to offer returned men?

Employment in forest protection is the most important from the national standpoint. It is not necessary to go into the importance of our forest resources nor the part they play in providing one of the most profitable sources of foreign exchange through their export. They must be protected. Hazards along highways, secondary roads and forest trails should be removed, and lands adjacent to railways cleared up. Fire lines could be cleared at strategic places, lookout towers built, telephone lines extended and roads and trails built to make access to dangerous sections easy.

Planting along highways and the building of places for tourists to camp would help our very important tourist traffic.

The checking of erosion is also very important and the planting up of the hundreds of square miles of sand dunes which have already caused and are causing a great deal of damage.

Planting on burns and sections which are not regenerating properly would furnish a vast amount of work both in the actual setting out of stock and in the nurseries necessary to furnish it.

Provincial, municipal and town forests would be set up and put in order and these could be made into recreational centres. The lack of these is a contributing factor to juvenile delinquency and the poor physical condition of our young people.

Improvement thinnings in sections near existing mills, on suitable areas, on farmers' woodlots, and on denuded slopes would add greatly to our national wealth and bring home to the public the value of our forests.

The setting up and care of experimental plots and demonstration areas is very desirable.

River and streams improvement and the building of forest roads would furnish many jobs and would be a great help to the lumber and pulp and paper industries. But here we run into a snag-the temporary nature of logging operations. Unless our large licensees change over to a sustained yield method of cutting, instead of the present cut and get out system which requires only temporary roads and improvements, such work would be of no value to the government owners of the land and they would not be justified in spending money for such work.

Forest colonies could also be set up and men employed in building houses, roads and public buildings. The lamentable lessons we have learned from the badly planned agricultural settlement policy which has been followed should be heeded and a scheme followed which would make such colonies furnish a decent livelihood. Churches, schools and recreation centres should be built. 
There would have to be enough arable land in the vicinity of such colonies to provide gardens for the inhabitants and logging methods would have to be changed to provide all year round employment.

The work mentioned in the last two paragraphs should not be undertaken unless the forest was under sustained yield management and as it is not likely that lumbermen and pulp and paper mills would adopt this method voluntarily, it would have to be made obligatory by the governments concerned. Such colonies would be especially suitable in Quebec, whose people are natural colonizers, love the work in the woods and their homes. The young men growing up in such places could be given training in logging and become really skilled workmen. This would do away in a large measure with camps and with the evils attendant on a floating labor supply.

The most important question is who will pay for such work. The woodusing industries owning timber lands should be asked to co-operate by taking all the men they can use but should not be asked to contribute directly to the cost of rehabilitation. The returned men are the responsibility of the federal government and the benefits of the work would accrue to the provinces. Therefore the cost should be shared between them and taxes should be levied to provide the funds. There is already a precedent for this in the National Forestry Program which was entirely successful.

In discussing the question of who shall pay for putting soldiers, warworkers and young men to work, we must remember that we are investing money and not just paying it out. The returns to the country in building up a body of satisfied trained men, gainfully employed, in improved production from forests and farmers' woodlots, in increased tourist traffic, in benefits to the wood-using industries will far exceed the money required. The reduction in supporting the unemployed and their families, in upkeep of prisons and insane asylums also must be added to the benefits to be derived.

If we could afford to take care of these men when they were fighting and working to save the country we can afford to continue to help them to get back into our peace time economy. It will be cheaper than the iniquitous dole and might be better than having to face the resentment and despair which will not be borne as it was after the last war and the crisis of the early thirties.

It cannot be too strongly emphasized that we must not look on this work as charitable or as a sort of dole for the unemployed, which was one of the most hellish makeshifts ever thought up. These men are the pick of our young manhood, the coming generation which is the hope of the world. We shall owe our freedom to them from a situation worse than death. If we can do everything to put and keep them in fighting trim to save our own skins we can well afford to do the same for them in peace. We can also escape the evils of war pensioners forming a lobby and draining the public treasury for generations as was done after the civil war and the first world war in the United States.

If I judge the temper of these men rightly, they are expecting a grateful country to give them a square deal and it will not be altogether wise to disappoint them. 